\title{
Correlation of serum alkaline phosphatase with clinicopathological characteristics of patients with oesophageal cancer
}

A. Aminian, ${ }^{1}$ F. Karimian, ${ }^{1}$ R. Mirsharifi, ${ }^{1}$ A. Alibakhshi, ${ }^{1}$ S.M. Hasani, ${ }^{1}$ H. Dashti, ${ }^{1}$ Y. Jahangiri, ${ }^{1}$ H. Ghaderi ${ }^{7}$ and A. Meysamie ${ }^{2}$

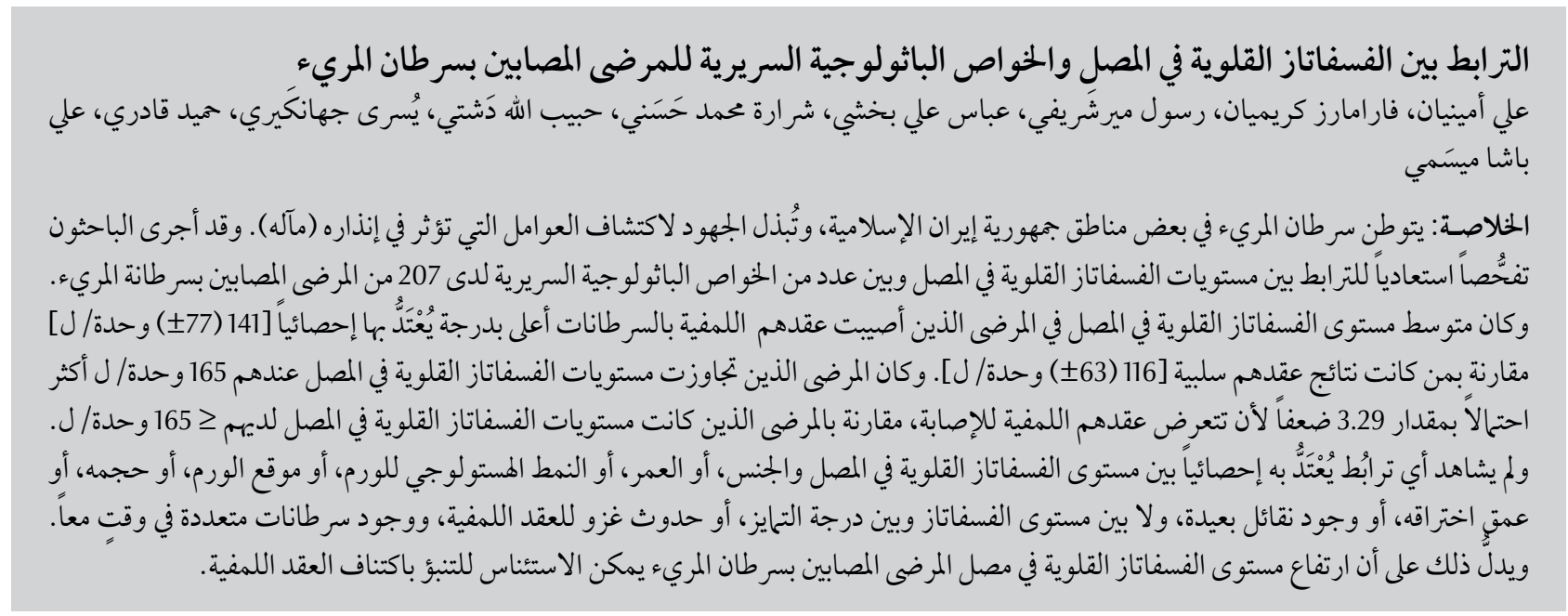

ABSTRACT Oesophageal cancer is endemic in some regions of the Islamic Republic of Iran and efforts have been made to find factors that play a role in its prognosis. We retrospectively examined the correlation of serum alkaline phosphatase (ALP) levels with several clinicopathological characteristics of 207 cases of oesophageal carcinoma. The mean ALP level in patients with lymph node involvement was significantly higher [141 (SD 77) U/L] than with node negative cancers [116 (SD 63) U/L]. Patients with ALP levels > $165 \mathrm{U} / \mathrm{L}$ were 3.29 times more likely to have lymph node involvement than patients with ALP levels $\leq 165 \mathrm{U} / \mathrm{L}$. There was no statistically significant correlation between ALP level and sex, age, tumour histological type, site and size of tumour, depth of penetration, distant metastasis, degree of differentiation, presence of lymphatic invasion and presence of simultaneous multiple cancers. Elevated ALP in patients with oesophageal cancer may predict lymph node involvement.

Corrélation entre la phosphatase alcaline sérique et les caractéristiques clinicopathologiques des patients atteints d'un cancer de l'œsophage

RÉSUMÉ Le cancer de l'œsophage étant endémique dans certaines régions de la République islamique d'Iran, des efforts ont été déployés pour identifier les facteurs qui jouent un rôle dans son pronostic. Nous avons examiné rétrospectivement la corrélation entre le taux de phosphatase alcaline sérique et plusieurs caractéristiques clinicopathologiques de 207 cas de carcinome de l'œsophage. Le taux moyen de phosphatase alcaline sérique chez les patients souffrant d'un cancer de l'œsophage avec atteinte des ganglions était significativement supérieur [141 (E.T. 77) U/I] au taux des autres patients [116 (E.T. 63) U/I]. Les patients ayant un taux de phosphatase alcaline sérique supérieur à $165 \mathrm{U} / \mathrm{I}$ avaient 3,29 fois plus de risque de présenter une atteinte ganglionnaire que les autres. Aucune corrélation statistiquement significative n'a été trouvée entre le taux de phosphatase alcaline sérique et le sexe, l'âge, le type histologique de la tumeur, sa localisation et sa taille, sa profondeur de pénétration, la présence de métastases à distance, le degré de différenciation, et la présence d'une atteinte des ganglions et de cancers multiples simultanés. Un taux élevé de phosphatase alcaline sérique chez les patients atteints d'un cancer de l'œsophage peut être un facteur prédictif d'une atteinte ganglionnaire. 


\section{Introduction}

Cancer of the oesophagus is the sixth most common cause of cancer-related mortality worldwide $[1,2]$. Oesophageal cancer is endemic in some regions of Islamic Republic of Iran $[3,4]$ and efforts have been made to find factors that play role in the prognosis of this disease.

Alkaline phosphatase (ALP) comprises a group of enzymes that catalyse the hydrolysis of phosphate esters in an alkaline environment, generating an organic radical and inorganic phosphate $[5,6]$. As with other enzymes, ALP has different isoenzymes. ALP is mainly derived from the liver and bones and in lesser amounts from intestines, placenta, kidneys and leukocytes.

Increases in serum ALP levels have been associated with a variety of hepatic and bone diseases, such as cholestasis, hepatitis and infiltrative liver disease [6]. Serum ALP levels are elevated in patients with primary and metastatic tumours of liver and bone, such as hepatic metastasis of colorectal cancer and bone and liver involvement in breast cancer [6]. In patients with malignancies, therefore, an elevated serum ALP level may be an indicator of metastatic disease. However, the association of ALP with other clinicopathological characteristics of cancers, such as the status of lymph node involvement, has not been fully evaluated.

In this study we examined the correlation of serum ALP level with several clinicopathological characteristics of oesophageal carcinoma.

\section{Methods}

\section{Sample}

A sample of 420 cases with oesophageal cancer undergoing oesophagectomy in a referral cancer institute in Tehran,
Islamic Republic of Iran during a 5-year period (2001-06) were studied retrospectively. The level of preoperative serum ALP was available in 207 cases. Neoadjuvant therapy and presence of other malignancies were considered as exclusion criteria. Patients with lower oesophageal tumours underwent transhiatal resection (Orringer technique) and those with mid- and upper-third oesophageal tumours had transthoracic oesophagectomy (Ivor Lewis or McKeown procedures).

\section{Data collection}

Data were collected retrospectively from patients' charts. The following information was recorded: pre-operative ALP level; patient's age and sex; site of tumour; presence of multiple cancers; and clinicopathologic characteristics including histology type, tumour size, depth of penetration ( $\mathrm{T}$ according to TNM classification), lymph node involvement ( $\mathrm{N}$ according to TNM classification), distant metastasis (Maccording to TNM classification), degree of differentiation, presence of vascular, lymphatic and perineural invasion, postoperative complications and in-hospital death.

Because there were a limited number of cases in penetration subgroups $\mathrm{T}_{1}$ and $\mathrm{T}_{2}$, the cases were classified as less penetrating tumours $\left(T_{1}\right.$ and $\mathrm{T}_{2}$ ) and more penetrating tumours $\left(\mathrm{T}_{3}\right.$ and $\left.\mathrm{T}_{4}\right)$.

\section{Analysis}

Levels of ALP in U/L are presented as the mean and standard deviation (SD).

The relation between ALP level and clinicopathological characteristics was assessed with chi-squared, Student ttest and Pearson correlation tests. In all cases the probability of type $1 \mathrm{er}$ ror $<0.05$ was taken as the criterion of significance. All statistical analyses were conducted using SPSS, version 11 computer program.

\section{Results}

The mean age of the 207 patients with oesophageal cancer was 63.3 (SD 11.4) years. Squamous cell carcinoma constituted $95 \%$ and adenocarcinoma 5\% of cases. Most cancers were in stage III, followed by stage II. Most tumours were located in the lower part of the oesophagus (59\%). The details of the clinicopathological findings are summarized in Table 1.

The overall mean ALP level was 126 (SD 70) U/L, range 53-438 U/L. The mean ALP level in patients with lymph node involvement was significantly higher $[141$ (SD 77) U/L] than in patients with node negative cancers [116 (SD 63) U/L], with a mean difference of 25 (SD 10) U/L $(P=0.022)$.

The cut-off point for maximum specificity and sensitivity was established as $165 \mathrm{U} / \mathrm{L}$ using receiver operating characteristic curve analysis. Patients with ALP level $>165 \mathrm{U} / \mathrm{L}$ were $>3$ times more likely to have lymph node involvement than patients with ALP level $\leq 165$ $\mathrm{U} / \mathrm{L}(\mathrm{OR}=3.29,95 \%$ confidence interval 1.58-6.84) $(P<0.001)$. Additionally, the level of ALP was significantly higher in the presence of vascular invasion $(P<0.001)$ and perineural invasion $(P=0.023)$ (Table 1).

There was no statistically significant correlation between the ALP level and sex, age, tumour histological type, site and size of tumour, depth of penetration $(\mathrm{T})$, distant metastasis $(\mathrm{M})$, degree of differentiation, presence of lymphatic invasion and presence of simultaneous multiple cancers (Table 1).

Table 2 summarizes the association between the ALP level and clinicopathological parameters in the subgroup of patients with squamous cell carcinoma $(n=185)$. In this subgroup analysis, the ALP level was also significantly higher in the presence of lymph node metastasis $(P=0.018)$ and vascular invasion $(P<0.001)$. We observed poor agreement between 


\begin{tabular}{|c|c|c|c|c|}
\hline Variable & No. & $\%$ & $\begin{array}{c}\text { ALP level (U/L) } \\
\text { Mean (SD) }\end{array}$ & $P$-value \\
\hline Sex & & & & 0.508 \\
\hline Male & 106 & 51 & $122(69)$ & \\
\hline Female & 101 & 49 & $129(71)$ & \\
\hline Type & & & & 0.848 \\
\hline Squamous cell carcinoma & 185 & 95 & $125(70)$ & \\
\hline Adenocarcinoma & 9 & 5 & $120(68)$ & \\
\hline Anatomical location & & & & 0.091 \\
\hline Upper & 4 & 2 & $94(19)$ & \\
\hline Middle & 70 & 39 & $115(63)$ & \\
\hline Lower & 105 & 59 & $137(76)$ & \\
\hline Degree of differentiation & & & & 0.349 \\
\hline Good & 47 & 27 & $118(67)$ & \\
\hline Moderate & 95 & 53 & $124(66)$ & \\
\hline Poor & 36 & 20 & $139(72)$ & \\
\hline Depth of penetration & & & & 0.735 \\
\hline $\mathrm{T}_{1}$ and $\mathrm{T}_{2}$ & 44 & 25 & $127(79)$ & \\
\hline $\mathrm{T}_{3}$ and $\mathrm{T}_{4}$ & 129 & 75 & $123(68)$ & \\
\hline Lymph nodes metastasis & & & & 0.022 \\
\hline Positive & 78 & 44 & $141(77)$ & \\
\hline Negative & 101 & 56 & $116(63)$ & \\
\hline Distant metastasis & & & & 0.429 \\
\hline Present & 7 & 4 & $107(42)$ & \\
\hline Absent & 170 & 96 & $128(71)$ & \\
\hline Lymphatic invasion & & & & 0.104 \\
\hline Present & 68 & 41 & $134(80)$ & \\
\hline Absent & 99 & 59 & $115(63)$ & \\
\hline Vascular invasion & & & & 0.001 \\
\hline Present & 76 & 43 & $144(68)$ & \\
\hline Absent & 101 & 57 & $106(58)$ & \\
\hline Perineural invasion & & & & 0.023 \\
\hline Present & 42 & 25 & $136(60)$ & \\
\hline Absent & 123 & 75 & $111(63)$ & \\
\hline Multiple cancers & & & & 0.213 \\
\hline Present & 7 & 4 & $94(17)$ & \\
\hline Absent & 173 & 96 & $129(73)$ & \\
\hline
\end{tabular}

$S D=$ standard deviation .

lymph node involvement and vascular invasion (kappa $=0.112, P=0.145)$. In the cross tabulation with chi-squared tests there was no significant association between these 2 parameters.

No association was found between ALP level and early post-operative morbidity and mortality of oesophageal cancer surgery (Table 3).

\section{Discussion}

Although the association between serum level of ALP and systemic metastases in malignancies have been demonstrated [7-15], the correlation between elevation of ALP and lymph node involvement has not been studied before $[5,6]$.
Pretreatment staging of patients with oesophageal cancer has a major role in decision-making about care. This is generally achieved by using imaging techniques. Local lymph nodes are generally the first site of tumour cell involvement outside the primary malignant focus in most solid tumours. Lymph node involvement plays a major 
role in the prognosis of patients with oesophageal cancer. Current imaging techniques, however, are not accurate enough to detect the presence and extent of lymph node involvement in many patients with oesophageal cancer. Additionally, no serum marker predictive of lymph node involvement has been suggested yet.
Correlation between elevation of ALP and lymph node involvement in solid tumours has not been studied before. In our study patients with serum ALP > $165 \mathrm{U} / \mathrm{L}$ had a significantly higher ( $>3$ times) probability of having metastatic lymph node involvement. Saif et al. reported that patients with colorectal cancer and ALP level > 160 $\mathrm{U} / \mathrm{L}$ were 12 times more likely to have a liver metastasis than patients with an
ALP level < 160 U/L [6]. The significant elevation of ALP in the presence of lymph node involvement in cases of oesophageal cancer for which no enzymatic or antigenic markers have been described may prove to be useful in the estimation of the extent of the tumour.

We conclude that elevated ALP in patients with oesophageal cancer may predict lymph node involvement.

\begin{tabular}{|c|c|c|c|c|}
\hline \multirow[t]{2}{*}{ Variable } & \multirow[b]{2}{*}{ No. } & \multicolumn{3}{|c|}{ ALP level (g/dL) } \\
\hline & & $\%$ & Mean (SD) & $P$-value \\
\hline Sex & & & & 0.458 \\
\hline Male & 96 & 51 & $121(69)$ & \\
\hline Female & 89 & 49 & $129(71)$ & \\
\hline Anatomical location & & & & 0.104 \\
\hline Upper & 4 & 2 & $94(19)$ & \\
\hline Middle & 66 & 40 & $114(64)$ & \\
\hline Lower & 95 & 58 & $136(77)$ & \\
\hline Degree of differentiation & & & & 0.306 \\
\hline Good & 47 & 29 & $118(67)$ & \\
\hline Moderate & 86 & 52 & $125(67)$ & \\
\hline Poor & 31 & 19 & $142(74)$ & \\
\hline Depth of penetration & & & & 0.969 \\
\hline $\mathrm{T}_{1}$ and $\mathrm{T}_{2}$ & 42 & 26 & $125(78)$ & \\
\hline $\mathrm{T}_{3}$ and $\mathrm{T}_{4}$ & 120 & 74 & $125(69)$ & \\
\hline Lymph nodes metastasis & & & & 0.018 \\
\hline Positive & 72 & 44 & $143(78)$ & \\
\hline Negative & 93 & 56 & $115(64)$ & \\
\hline Distant metastasis & & & & 0.276 \\
\hline Present & 6 & 4 & $96(34)$ & \\
\hline Absent & 156 & 96 & $128(72)$ & \\
\hline Lymphatic invasion & & & & 0.095 \\
\hline Present & 64 & 41 & $134(79)$ & \\
\hline Absent & 91 & 59 & $114(64)$ & \\
\hline Vascular invasion & & & & 0.0001 \\
\hline Present & 70 & 43 & $144(69)$ & \\
\hline Absent & 91 & 57 & $105(57)$ & \\
\hline Perineural invasion & & & & 0.071 \\
\hline Present & 36 & 24 & $133(61)$ & \\
\hline Absent & 114 & 76 & $111(63)$ & \\
\hline Multiple cancers & & & & 0.229 \\
\hline Present & 7 & 4 & $94(17)$ & \\
\hline Absent & 160 & 96 & $127(73)$ & \\
\hline
\end{tabular}

$S D=$ standard deviation . 


\begin{tabular}{|c|c|c|c|c|}
\hline Variable & No. & $\%$ & $\begin{array}{c}\text { ALP level (U/L) } \\
\text { Mean (SD) }\end{array}$ & $P$-value \\
\hline Complications & & & & 0.754 \\
\hline Present & 50 & 28 & $124(77)$ & \\
\hline Absent & 128 & 72 & $128(70)$ & \\
\hline Pulmonary complications & & & & 0.749 \\
\hline Present & 22 & 11 & $121(63)$ & \\
\hline Absent & 184 & 89 & $126(71)$ & \\
\hline Cardiovascular complications & & & & 0.312 \\
\hline Present & 4 & 2 & $161(106)$ & \\
\hline Absent & 203 & 98 & $125(69)$ & \\
\hline Anastomotic leakage & & & & 0.713 \\
\hline Present & 25 & 12 & $121(84)$ & \\
\hline Absent & 182 & 88 & $126(68)$ & \\
\hline Death & & & & 0.288 \\
\hline Yes & 10 & 6 & $100(33)$ & \\
\hline No & 168 & 94 & $125(72)$ & \\
\hline
\end{tabular}

$S D=$ standard deviation .

Moreover, a cut-off level of $165 \mathrm{U} / \mathrm{L}$ may be considered as a major risk factor for lymph node involvement in patients with oesophageal cancer. Obviously these findings should be confirmed in further studies to provide more evidence for their application in clinical practice.

\section{References}

1. Parkin DM et al. Global cancer statistics 2002. CA: a Cancer Journal for Clinicians, 2005, 55:74-108.

2. Kamangar $\mathrm{F}$ et al. Patterns of cancer incidence, mortality, and prevalence across five continents: defining priorities to reduce cancer disparities in different geographic regions of the world. Journal of Clinical Oncology, 2006, 24:2137-2150.

3. Mohagheghi MA et al. Cancer incidence in Tehran metropolis: the first report from the Tehran population-based cancer registry, 1998-2001. Archives of Iranian Medicine, 2009, 12:15-23.

4. Alibakhshi $\mathrm{A}$ et al. The effect of age on the outcome of esophageal cancer surgery. Annals of Thoracic Medicine, 2009, 4:71-74.

5. Reichling J, Kaplan MM. Clinical use of serum enzymes in liver diseases. Digestive Diseases and Sciences, 1988, 33:16011604.

6. Saif MW, Alexander D, Wicox CM. Serum alkaline phosphatase level as a prognostic tool in colorectal cancer: a study of 105 patients. Journal of Applied Research, 2005, 5:88-95.

7. Ben-Arie A et al. Elevated serum alkaline phosphatase may enable early diagnosis of ovarian cancer. European Journal of $\mathrm{Ob}$ stetrics, Gynecology, and Reproductive Biology, 1999, 86:69-71.
8. Millán JL, Fishman WH, Stinson R. Biology of human alkaline phosphatases with special reference to cancer. Critical Reviews in Clinical Laboratory Sciences, 1995, 32:1-39.

9. Warnes TW. Alkaline phosphatase. Gut, 1972, 13:926-937.

10. Fishman WH et al. Immunology and biochemistry of Regan isoenzyme of alkaline phosphatase in human cancer. Nature, 1968, 219:697-699.

11. Muensch HA et al. Placental-like alkaline phosphatase. Reevaluation of the tumor marker with exclusion of smokers. Cancer, 1986, 58:1689-1694.

12. Mano $\mathrm{H}$ et al. Radioimmunoassay of placental alkaline phosphatase in ovarian cancer sera and tissues. Obstetrics and Gynecology, 1986, 68:759-764.

13. Massey GV et al. Benign transient hyperphosphatasemia in children with leukemia and lymphoma. Clinical Pediatrics, 1996, 35:501-504.

14. Rassam MB et al. Heat-stable alkaline phosphatase. A putative tumor marker of head and neck squamous cell carcinoma. Acta Oncologica (Stockholm, Sweden), 1995, 34:49-52.

15. Skinner JM, Whitehead R. Carcinoplacental alkaline phosphatase in malignant and premalignant conditions of the human digestive tract. Virchows Archiv. A, Pathological Anatomy and Histology, 1981, 394:109-118. 